\title{
HYDROCARBONS AND ORGANOCHLORINE PESTICIDES IN SOILS OF THE URBAN ECOSYSTEM OF CHILLÁN AND CHILLÁN VIEJO, CHILE
}

\author{
MARTA HENRÍQUEZ ${ }^{1,2}$, JOSÉ BECERRA ${ }^{3}$, RICARDO BARRA ${ }^{4}, J O R G E ~ R O J A S^{5}$
}

\author{
${ }^{1}$ Programa de Doctorado en Ciencias Ambientales. Centro EULA-Chile, Universidad de Concepción, Concepción, Chile \\ ${ }^{2}$ Departamento de Ciencias Sociales, Escuela de Historia y Geografía, Facultad de Educación, Universidad del Bío-Bío, Chillán, Chile \\ ${ }^{3}$ Laboratorio de Química de Productos Naturales, Departamento de Botánica, Facultad de Ciencias Naturales y Oceanográficas, Universidad de Concepción, \\ Concepción, Chile \\ ${ }^{4}$ Unidad de Sistemas Acuáticos, Centro EULA-Chile, Universidad de Concepción, Concepción, Chile \\ ${ }^{5}$ Departamento de Sociología, Facultad de Ciencias Sociales, Universidad de Concepción, Concepción, Chile
}

\begin{abstract}
Although traditional soil use in Chillán and Chillán Viejo is agricultural, both cities have seen their surrounding areas expand and change drastically. Economic activities have increased, including phytosanitary companies and petroleum derivatives used in agriculture and transport. This has had a large impact on the soil.

The present work studies total hydrocarbon contamination (lineal and polycyclic aromatics) and chlorine pesticides (Aldrin, Dieldrin, DDT, and DDE) in surface soils near potential sources of pollution.

The concentration of total hydrocarbons in the majority of the samples analyzed is between 0.1 and $70 \mathrm{mg} / \mathrm{kg}$. Only $8.8 \%$ exceed $70 \mathrm{mg} / \mathrm{kg}$., indicating the need for recovery before use, according international regulations.

The pesticide Aldrin was found in $41.2 \%$ of the soil samples, DDT in $32.4 \%$, Dieldrin in $29.4 \%$, and DDE in $2.9 \%$. These levels exceed the maximum limits established for ecological improvement in Chile. Amongst themselves, total hydrocarbons correlated with total pesticides and with DDT, but not with Aldrin or Dieldrin. Correlations were also found for total pesticides with DDT and Aldrin, and strong correlations were observed for DDT with Aldrin, and Aldrin with Dieldrin.
\end{abstract}

Keywords: hydrocarbons, pesticides, surface soil texture, mid-city

\section{INTRODUCTION}

Few studies of urban soil pollution have been carried out in Chile. Contamination with hydrocarbons and organochlorines has been detected in the Biobío Region. Between 1987 and 1989, agricultural soils near the Laja and Biobío rivers were found to have the following concentrations: $0.5-5.0 \mathrm{mg} /$ $\mathrm{kg}$ Dieldrin, $0.5 \mathrm{mg} / \mathrm{kg}$ Aldrin, and DDE; DDT was not observed ${ }^{1)}$. In 1998 , total aromatic hydrocarbons $(61.8 \pm 2.7 \mathrm{mg} / \mathrm{kg})$ were found in surface soils in the city of Talcahuano, although no relationship was found between soil texture and the concentrations of these pollutants ${ }^{2,3}$. More recent reports, in soil samples from the Laja river basin reports quite low concentrations both of chlorinated compounds and Polyciclic Aromatic Hydrocarbons (PAHs), in the latter case the highest concentrations were found nearby of a saw mill area ${ }^{4)}$

Several studies have focused on the factors responsible for the adsorption processes of persistent organochlorine compounds ${ }^{5}$. For example, when the partition coefficient (Koc) surpasses 100,000, the compounds are adsorbed by the soil with greater force. In the case of DDT, the adsorption coefficient is 240,000 , and that of DDE is five times greater than that of DDD $(780,000)$ 6. Nevertheless, some organizations estimate that DDT, Aldrin, and Dieldrin have a Koc of $10^{577}$. The adsorption coefficients of PAHs with low molecular weights oscillate between $10^{3}$ and $10^{4}$; intermediate molecular weight PAHs have adsorption coefficients of $10^{4}$, and those with high molecular weights are between $10^{5}$ and $10^{6} 7$ ). The factors that intervene in the adsorption process of these organic compounds ${ }^{1,6,9,10)}$ are clay type and content, organic matter, and humidity, even in sediments from lake systems ${ }^{10,11}$. Climatic factors like temperature, precipitation, and evapotranspiration also influence the behavior of these compounds.

The aim of this paper was to investigate the levels of total hydrocarbon compounds and several organochlorine pesticides in urban soils in the cities of Chillán and Chillán Viejo, since these towns have growth significatively during the last 20 years, towards former agricultural areas, and to relate the levels found with some soil properties such as texture and organic matter content. In addition it is hypothesized that cities are diffuse centers of PAHs pollutants from vehicle and combustion emissions, whereas they are receiving pesticide loads from nearby arable lands. ${ }^{12)}$

Finally, observed levels are compared with international regulations such as the Netherlands quality criteria for soils ${ }^{13,14}$, since Chile lacks of such kind of regulations.

\section{MATERIALS AND METHODS}

\section{Study area}

Chillán and Chillán Viejo are located in central-southern Chile, in the central valley between the Andes Mountain Range (east) and the Coastal Mountain Range (west). The cities are laid out in a flat, slightly hilly area, with the northern edge not exceeding $170 \mathrm{~m}$ altitude and the southern edge not exceeding $109 \mathrm{~m}$.

The urban area sits in the Itata River Valley, between two tributaries: Nuble River and Chillán River. The rivers are found in the sub-valley of the Las Toscas Estuary, tributary of the Chillán River, consisting of the Luz de Cato Canal and the Camarones and Las Lechuzas channels. Urban expansion covered 932 hectares of agricultural lands between 1978 and 2000. ${ }^{15}$

\section{Sampling sites and urban surface soil treatments}

A total of 34 sites were selected for sampling in Chillán and Chillán Viejo. The sites, between 5 and $10 \mathrm{~m}$ from potential contamination sources, are indicated on the map of the two urban centers (Plan 1).

In April 2001, samples of undisturbed soils were taken, where no digging was being done, to a depth of $10 \mathrm{~cm}$. Sites free of pavement were chosen, such as areas beside sidewalks and on traffic islands dividing avenues. Some were grassy, others bare, and others had sparse vegetation or trees.

Approximately $1 \mathrm{~kg}$ of soil was extracted with clean gardening shovels, taking care not to contaminate the samples with any substances surrounding the site. The samples were placed in aluminum foils and polyethylene bags, sealed, identified numerically with masking tape, and stored in a freezer $\left(-20^{\circ} \mathrm{C}\right)$ until being sent to the laboratory. At the same time, the sampling sites were located on a scale $(1: 10.000)$ map of Chillán and Chillán Viejo. These were then entered on an urban map using the Geographic Information System (GIS), MapInfo. The final map, showing the spatial distribution of hydrocarbons and organochlorine pesticide pollution, was cleaned up with Macromedia FreeHand 9 . 


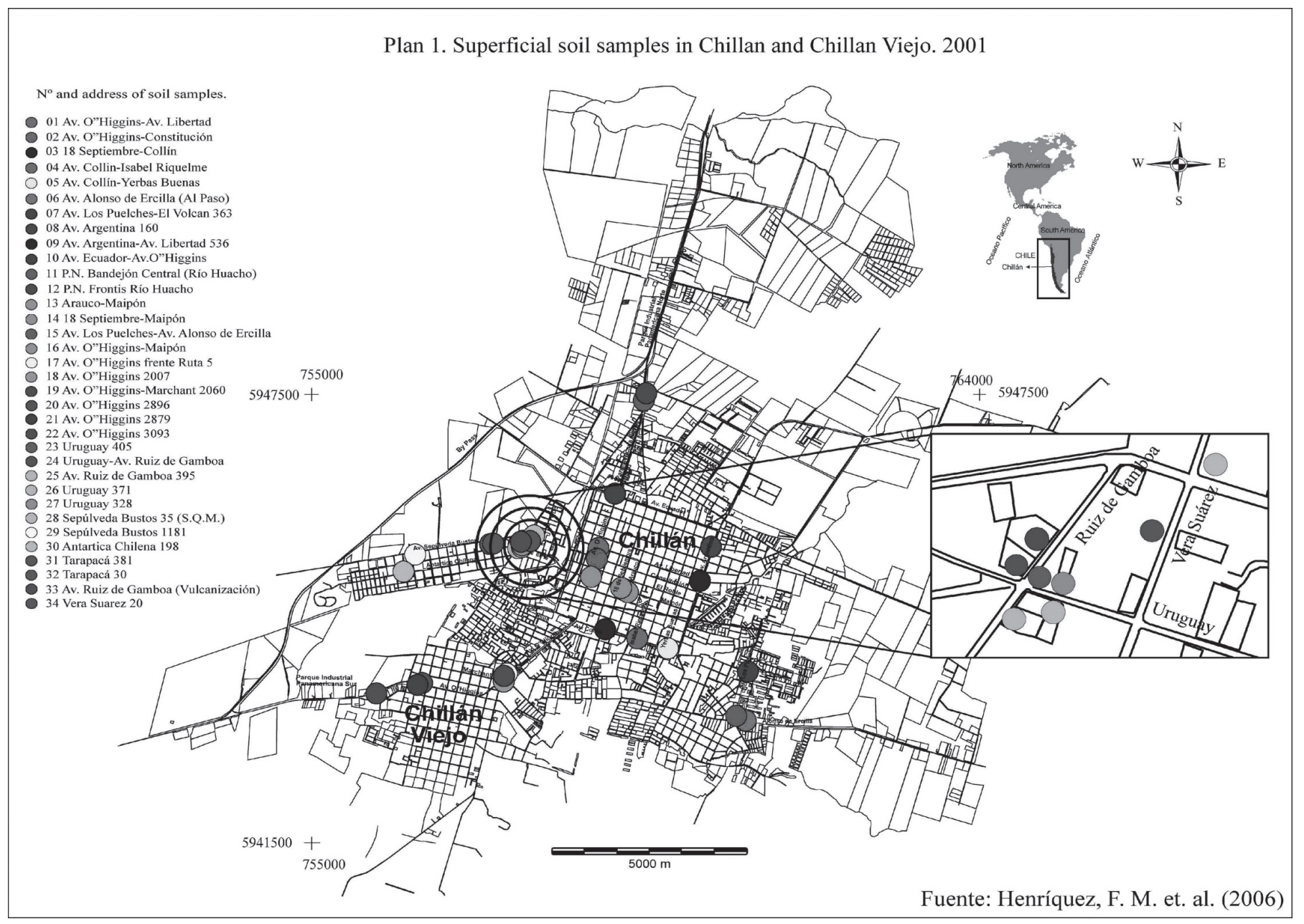

\section{Sample analysis}

Soil samples were homogenized and analyzed in the laboratory of Chemistry of Natural Products at the Faculty of Natural and Oceanographic Sciences, University of Concepción, with a 200 mesh sieve to separate vegetable matter from solid bits.

Humidity was established by drying the samples at $105^{\circ} \mathrm{C}$ and determining the total organic matter by calcination at $500^{\circ} \mathrm{C}$. The soil sample texture was analyzed according to the USDA system in the laboratory of the Department of soil, Faculty of Agronomy, University of Concepción. This system reveals the percentages of clay, mud, and sand that make up the soil.

The chemical detection of aromatic polycyclic hydrocarbons was done with gas chromatography-mass spectrometry and total hydrocarbons were analyzed by ultraviolet spectrometry. First the hydrocarbons were separated into a silice gel column in four fractions: lineal aromatics (F1: n-paraffin's, F2: solvents) and polycyclic aromatic hydrocarbons (F3: aromatics and monoand bicyclics and F4: polycyclic aromatics). The F3 and F4 fractions were investigated with ultraviolet spectrometry and gas-mass chromatography, respectively. The analysis of DDT, DDE, Aldrin, and Dieldrin was done with gas chromatography with electron capture detectors according Pastor et al. ${ }^{16}$.
PAHs were analyzed in a GC-MS HP5890 using a HP5-MS column 30 $\mathrm{m}, 025 \mathrm{id} ., 0.25 \mu \mathrm{m}$ particle size, the temperature program was $60^{\circ} \mathrm{C}$ for $5 \mathrm{~min}$ then $10^{\circ} \mathrm{C} / \mathrm{min}$ up to $275^{\circ} \mathrm{C}$. Detection was performed using both Scan and SIM methods.

Organochlorine pesticides were assessed using GC Shimadzu 9A with an Electron Capture Detector (ECD). Nitrogen was used as gas carrier; the chromatographic column was a HP-5. Temperature program was as follows: initial $215^{\circ} \mathrm{C}$ and then $10^{\circ} \mathrm{C} / \mathrm{min}$ up to $250^{\circ}$. The detection limits of the method were $0,1 \mathrm{mg} / \mathrm{kg} \mathrm{dw}$ for total hydrocarbons and $0,01 \mathrm{mg} / \mathrm{kg} \mathrm{dw}$ for individual chlorinated pesticides. They were determined as the signal noise ratio $>3$.

The relationships of pesticides, lineal hydrocarbons, and polycyclic aromatic concentrations with surface soil organic matter, humidity, and textures were established through Pearson's correlation coefficient (r). The index (-1.0 to 1.0) indicates the degree of linear dependence between the two data sets of the positive samples.

The distribution of the proportions of total hydrocarbons and pesticides was also obtained for the different soil uses and potential contamination sources in both cities. 
Table 1. Physical and chemical characteristics, uses, and potential sources of pollutants in surface soils of

\begin{tabular}{|c|c|c|c|c|c|c|c|c|c|c|c|c|c|}
\hline \multirow{3}{*}{$\begin{array}{l}\text { Sample } \\
\text { No. }\end{array}$} & \multirow{3}{*}{$\begin{array}{c}\begin{array}{c}\text { Organic } \\
\text { matter }\end{array} \\
(\%)\end{array}$} & \multirow{3}{*}{$\begin{array}{l}\text { Humidity } \\
\text { (\%) }\end{array}$} & \multicolumn{9}{|c|}{ Chillán and Chillán Viejo. } & \multirow{3}{*}{$\begin{array}{c}\text { Soil } \\
\text { cover }\end{array}$} & \multirow{3}{*}{$\begin{array}{l}\text { Urban source } \\
\text { of } \\
\text { contamination }\end{array}$} \\
\hline & & & \multicolumn{3}{|c|}{ Textura (USDA) } & $\begin{array}{l}\text { Total } \\
\text { hydrocarbor }\end{array}$ & $\begin{array}{l}\text { Total } \\
\text { pesticides }\end{array}$ & & & & & & \\
\hline & & & $\begin{array}{l}\text { Sand } \\
(\%)\end{array}$ & $\begin{array}{l}\text { Mud } \\
(\%)\end{array}$ & $\begin{array}{l}\text { Clay } \\
(\%)\end{array}$ & $\mathrm{mg} / \mathrm{kg}$ & $\mathrm{mg} / \mathrm{kg}$ & $\begin{array}{l}\mathrm{DDT} \\
\mathrm{mg} / \mathrm{kg}\end{array}$ & $\begin{array}{l}\mathrm{DDE} \\
\mathrm{mg} / \mathrm{kg}\end{array}$ & $\begin{array}{l}\text { Aldrin } \\
\mathrm{mg} / \mathrm{kg}\end{array}$ & $\begin{array}{l}\text { Dieldrin } \\
\mathrm{mg} / \mathrm{kg}\end{array}$ & & \\
\hline 1 & 5.92 & 10.84 & 51.7 & 30.0 & 18.3 & 6.05 & 6.04 & 5.14 & ND & 0.38 & 0.52 & $\begin{array}{l}\text { Sparse } \\
\text { grass }\end{array}$ & $\begin{array}{l}\text { Gasoline } \\
\text { sales }\end{array}$ \\
\hline 2 & 16.60 & 14.70 & 37.3 & 43.3 & 19.4 & 7.00 & ND & ND & ND & ND & ND & Bare & $\begin{array}{l}\text { Gasoline } \\
\text { sales }\end{array}$ \\
\hline 3 & 2.61 & 14.07 & 74.8 & 17.0 & 8.2 & 8.65 & 1.26 & ND & ND & 1.26 & ND & Bare & $\begin{array}{l}\text { Gasaline } \\
\text { sales }\end{array}$ \\
\hline 4 & 3.16 & 11.77 & 64.9 & 25.6 & 9.5 & 7.87 & ND & ND & ND & ND & ND & Bare & $\begin{array}{l}\text { Gasoline } \\
\text { sales } \\
\text { Gasoline }\end{array}$ \\
\hline 5 & 3.90 & 6.05 & 81.5 & 14.0 & 4.5 & ND & ND & ND & ND & ND & ND & Bare & sales \\
\hline 6 & 3.15 & 3.97 & 81.6 & 15.0 & 3.4 & 5.33 & ND & ND & $\mathrm{ND}$ & ND & ND & Bare & $\begin{array}{l}\text { Tire services } \\
\text { Gasoline }\end{array}$ \\
\hline 7 & 5.44 & 6.67 & 66.3 & 26.6 & 7.1 & 8.04 & 0.10 & ND & ND & ND & 0.10 & Bare & \\
\hline 8 & 8.19 & 10.24 & 62.2 & 22.4 & 15.4 & 15.10 & 19.67 & 13.64 & 0.55 & 0.86 & 4.62 & Bare & sales \\
\hline 9 & 11.65 & 12.38 & 39.4 & 44.1 & 16.5 & 7.52 & 6.42 & 1.76 & ND & ND & 4.66 & Lawn & $\begin{array}{l}\text { sables } \\
\text { Gasoline }\end{array}$ \\
\hline 10 & 5.11 & 8.38 & 70.5 & 20.4 & 9.1 & 4.06 & 2.83 & 2.83 & ND & ND & ND & Bare & $\begin{array}{l}\text { sales } \\
\text { Pesticide }\end{array}$ \\
\hline 11 & 7.02 & 6.25 & 64.3 & 26.6 & 9.1 & 6.49 & ND & ND & ND & ND & ND & Lawn & \\
\hline 12 & 7.28 & 6.04 & 63.9 & 22.7 & 13.4 & 4.47 & 0.39 & ND & ND & 0.39 & ND & & \\
\hline 13 & 5.37 & 10.68 & 75.2 & 18.0 & 6.8 & 2.44 & ND & ND & ND & ND & ND & $\begin{array}{l}\text { Sparse } \\
\text { grass }\end{array}$ & $\begin{array}{l}\text { Gasoline } \\
\text { sales } \\
\text { Gasoline }\end{array}$ \\
\hline 14 & 17.10 & 6.04 & 52.1 & 44.2 & 3.7 & 5.95 & 0.81 & ND & ND & 0.81 & ND & Bare & sales \\
\hline 15 & 3.39 & 10.55 & 69.2 & 21.3 & 9.5 & 38.39 & 0.38 & ND & ND & 0.38 & ND & Bare & $\begin{array}{l}\text { Tire services } \\
\text { Gasoline }\end{array}$ \\
\hline 16 & 8.78 & 19.17 & 59.9 & 27.5 & 12.6 & 1.25 & 0.12 & ND & ND & 0.12 & ND & $\begin{array}{l}\text { Bare } \\
\text { Sarse }\end{array}$ & \\
\hline 17 & 5.51 & 4.08 & 73.1 & 20.0 & 6.9 & 10.30 & ND & ND & ND & ND & ND & & Tire services \\
\hline 18 & 4.24 & 2.74 & 81.5 & 14.0 & 4.5 & 15.38 & ND & $\mathrm{ND}$ & ND & ND & ND & gra & Tire services \\
\hline 19 & 3.98 & 1.98 & 80.5 & 17.1 & 2.4 & $\mathrm{ND}$ & ND & ND & ND & ND & ND & grass & $\begin{array}{l}\text { Tire services } \\
\text { Gasoline }\end{array}$ \\
\hline 20 & 5.05 & 4.17 & 77.0 & 21.6 & 1.4 & 13.38 & 1.01 & 1.01 & ND & ND & 1.01 & Lawn & \\
\hline 21 & 3.56 & 3.03 & 73.3 & 19.2 & 7.5 & 845.50 & ND & ND & ND & ND & ND & $\begin{array}{l}\text { Bare } \\
\text { Sparse }\end{array}$ & $\begin{array}{l}\text { cent } \\
\text { Elect }\end{array}$ \\
\hline 22 & 19.09 & 1.93 & 87.2 & 12.0 & 0.8 & ND & 1.90 & 1.23 & ND & 0.67 & ND & grass & $\begin{array}{l}\text { work } \\
\text { Hard }\end{array}$ \\
\hline 23 & 10.54 & - & 81.7 & 15.9 & 2.4 & $\mathrm{ND}$ & 70.46 & 65.40 & ND & 5.06 & ND & Bare & store \\
\hline 24 & 2.18 & 2.20 & 72.3 & 22.9 & 4.8 & 14.92 & 0.40 & ND & ND & ND & 0.40 & Bare & Tire services \\
\hline 25 & 10.45 & 11.91 & 57.6 & 26.1 & 16.3 & 14.43 & 2.95 & 2.15 & ND & ND & 0.80 & Bare & \\
\hline 26 & 4.96 & 4.24 & 54.2 & 30.5 & 15.3 & 7.58 & 7.34 & 4.41 & ND & 0.59 & 2.34 & Bare & \\
\hline 27 & 15.47 & 6.63 & 62.8 & 26.2 & 11.0 & ND & 51.83 & 43.78 & ND & 2.26 & 5.79 & Bare & $\begin{array}{l}\text { Turnery } \\
\text { Pesticide }\end{array}$ \\
\hline 28 & 15.18 & 2.76 & 66.5 & 28.5 & 5.0 & 1.92 & ND & ND & ND & ND & ND & & \\
\hline 29 & 10.07 & 2.90 & 80.6 & 15.0 & 4.4 & ND & 0.84 & ND & ND & 0.84 & ND & & Lumber yard \\
\hline 30 & 5.59 & 7.09 & 52.5 & 42.6 & 4.9 & $\mathrm{ND}$ & 0.18 & ND & ND & 0.18 & ND & & Lumber yard \\
\hline 31 & 4.58 & 3.23 & 62.8 & 30.2 & 7.0 & 0.22 & ND & ND & ND & ND & ND & $\begin{array}{l}\text { grass } \\
\text { Sparse }\end{array}$ & $\begin{array}{l}\text { Tire services } \\
\text { Mechanical }\end{array}$ \\
\hline 32 & 20.25 & 11.67 & 91.6 & 6.6 & 1.8 & 188.42 & $\mathrm{~N}$ & ND & ND & ND & ND & grass & \\
\hline 33 & 5.7 & 11.79 & 56.0 & 25.7 & 18.3 & 93. & 62.70 & 61.05 & $\mathrm{ND}$ & $\mathrm{ND}$ & 1.65 & Bare & Tire services \\
\hline ND: No & 1.84 & 2.84 & 79.3 & 13.8 & 6.9 & 59.77 & 0.50 & ND & $\mathrm{ND}$ & 0.38 & 0.12 & Bare & Motor repair \\
\hline
\end{tabular}

\section{RESULTS AND DISCUSSION}

The physical characteristics (total organic matter, humidity, texture) of the surface soils in Chillán and Chillán Viejo are shown in the table 1. Later, the chemical characteristics, that is, the concentration of organochlorine compounds such as total hydrocarbons and total pesticides (DDT, DDE, Aldrin, and Dieldrin) were analyzed.

The soil use determined the type of coverage at the sampling sites. The potential sources of pollutants corresponded to urban economic activities near the sampling site (Table 1).

Total hydrocarbons contaminated $82 \%$ of all the sample sites analyzed. Using the standards set for the Netherlands ${ }^{13,14)}, 47 \%$ of the sampled surface soils exceeded $7.0 \mathrm{mg} / \mathrm{kg}$, indicating the need for investigation prior to use and $9 \%$ surpassed $70 \mathrm{mg} / \mathrm{kg}$, requiring recovery (Table 1)

Spatial distribution of surface soils contaminated with total hydrocarbons.

The following plan of downtown Chillán (Libertad, Maipón, Arauco,
O'Higgins, Ecuador streets) and the area to the southeast of the city (Los Puelches-El Volcán and Los Puelches-Alonso de Ercilla) reveals soils with demonstrable contamination levels that should be investigated before any use, according the regulations of the Netherlands. This contamination could be due to neighboring tire services and gasoline distributors. Contamination was also found in the soils to the west of Chillán (Uruguay, Ruiz de Gamboa, Vera Suárez streets). In this area, many sites require investigation and others recovery. This pollution comes from the large number of tire services, mechanical workshops, turneries, lumber yards, and motor repair shops here. No total hydrocarbons were detected in the soils of Sepúlveda Bustos and Antártica Chilena streets (Plan 2).

In Chillán Viejo, the sites at O'Higgins 2007 and 2896 and O'Higgins-Ruta 5 were contaminated with total hydrocarbons, requiring investigation prior to use and at O'Higgins 2879 the soils need to be recovered. All these sites are near businesses engaging in gasoline sales, tire services, or mechanical workshops. No total hydrocarbons were found at O'Higgins 3093 and O'Higgins-Marchant 2060 (Plan 2). 
Plan 2. Spatial pollution distribution by total hidrocarbons in urban superficial soils in Chillan and Chillan Viejo. 2001
Standard of pollution according to Netherlands quality criteria for soils.
出 Non detected
Pollution demonstrable
Soils should be investigated before used
$\star$ Soils should cleansed

$$
\begin{aligned}
& >0,1 \mathrm{mg} / \mathrm{kg} \\
& >7,0 \mathrm{mg} / \mathrm{kg} \\
& >70,0 \mathrm{mg} / \mathrm{kg}
\end{aligned}
$$

(F. Mapfre, 1994; Danish EPA, 2000)
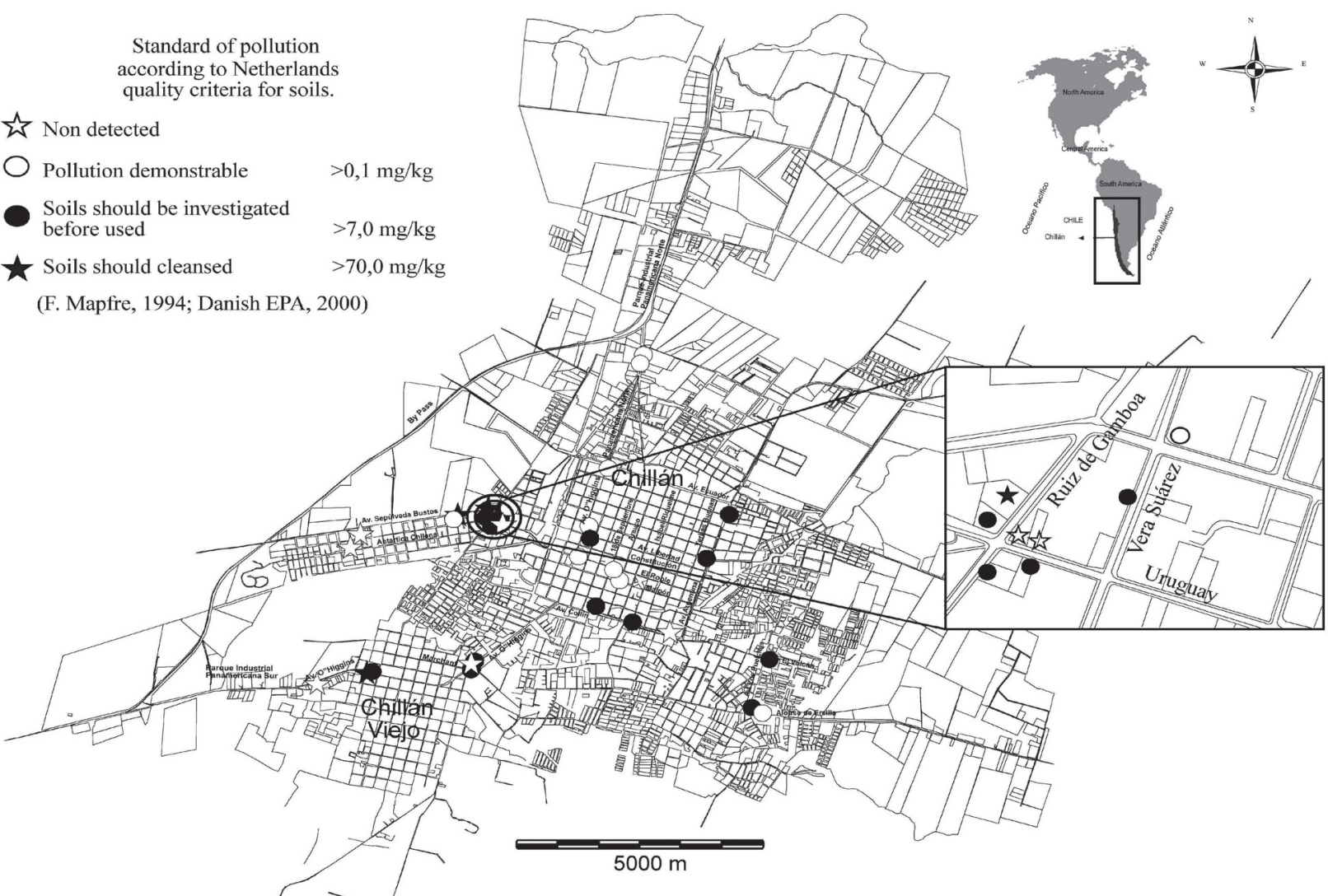

Fuente: Henríquez, F. M. et. al. (2006)
Spatial distribution of surface soils contaminated with pesticides

The chemical analysis of the total pesticides showed that $59 \%$ of the soils samples are contaminated with these compounds. Of all the polluted samples, $70 \%$ contained Aldrin, $55 \%$ DDT, 50\% Dieldrin, and 5\% DDE (small amounts). Half of these soil samples contained one of the pesticides researched, $30 \%$ had two, $15 \%$ had three, and $5 \%$ had all four pesticides (Table 1 ).

The spatial distribution of the soils with organochlorine pesticides exceeded the standard maximum amounts permitted, as established by the Chilean Agricultural and Livestock Service (SAG) for the protection of grasslands and ecological improvement. For soil treatment benefiting agriculture and ecological improvement, the SAG has set a maximum permitted level of $0.5 \mathrm{mg} / \mathrm{kg}$ DDT, $0.02 \mathrm{mg} / \mathrm{kg}$ Aldrin, and $0.02 \mathrm{mg} / \mathrm{kg}$ DDE and $0,02 \mathrm{mg} / \mathrm{kg}$ Dieldrin in grasslands and areas of ecological improvement ${ }^{17}$ ). Such standards are referential, because urban soil contamination processes are not regulated in Chile.

For example, to the west of Chillán (inset, plan 2), several urban sites (Av. Ruiz de Gamboa, Uruguay 405, Uruguay-Ruiz de Gamboa, Ruiz de Gamboa 395 , Uruguay 328$)$ are contaminated with Aldrin $(253 \pm 63$ times the maximum value permitted), Dieldrin (290 \pm 231$)$, and DDT $(327 \pm 88)$. This could be due to past agricultural use with unpaved streets and sidewalks or to filling with material taken from riverbanks, agricultural lands, or agricultural residue.

The urban settlement is on a terrace of fluvial-volcanic deposits, apparently compacted and impermeable, with a hydromorphism ${ }^{18)}$ that impedes the migration of chemicals to deeper layers since the clay colloids in the soil swell in humid conditions, inhibiting the filtration of water. This may be more frequent in recently moved soils. The possibilities of greater humidity content increase when considering anthropic factors like deforestation for road-building and the installation of urban and suburban infrastructure ${ }^{19}$. Moreover, Aldrin and Dieldrin are not easily leached from the soil by water (Plan 3).
DDT levels for the so-called four avenues of Chillán surpassed the maximum permitted amount by $5.6 \pm 2.0$ times (Ecuador with O'Higgins and Argentina with Libertad) and 27.3 8.8 times (Argentina 160 and O'Higgins with Libertad). Furthermore, Aldrin and/or Dieldrin levels exceeding the permitted amounts were also found in all the sites mentioned above. At Argentina 160, the metabolite DDE was found to be 28 times the permitted maximum for urban ecological improvement (Plan 3).

In Chillán Viejo, Aldrin and DDT were found to be $43 \pm 6$ times the allowed amount at O'Higgins 2896. DDE levels were similar at this site and at O'Higgins 3093, that is, 5.6 \pm 2.0 times the allowed value (Plan 3).

Average concentration and Pearson's correlation for organochlorine compounds

Average values of samples contaminated with organochlorines indicate that the greatest concentrations are of total hydrocarbons $(51.6 \mathrm{mg} / \mathrm{kg})$, followed by DDT and pesticides, in the surface soils of both cities. DDE was found in one sample and at lower concentrations than DDT, Aldrin, and Dieldrin (Table 2).

Table 2. Average concentrations of organochlorine compounds in samples of surface soils from Chillán and Chillán Viejo

$\begin{array}{cc}\begin{array}{c}\text { Compounds } \\ \text { Total }\end{array} & \mathrm{mg} / \mathrm{kg} \\ \text { hydrocarbons } & 51.6 \\ \text { Total Pesticides } & 11.3 \\ \text { DDT } & 16.9 \\ \text { DDE } & 0.6 \\ \text { Aldrin } & 1.0 \\ \text { Dieldrin } & 2.1\end{array}$


Plan 3. Spatial pollution distribution by organochlorine pesticides in urban superficial soils in Chillan and Chillan Viejo. 2001

Standard for the ecological improvement. $(*)$

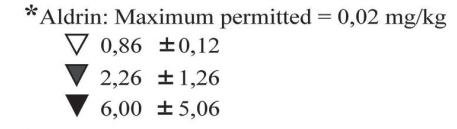

*Dieldrin: Maximum permitted $=0,02 \mathrm{mg} / \mathrm{kg}$ 公 $0,80 \pm 0,10$

‘ $2,34 \pm 1,65$

$+5,79 \pm 4,62$

*DDT: Maximum permitted $=0,5 \mathrm{mg} / \mathrm{kg}$

○ $2,83 \pm 1,01$

$13,64 \pm 4,41$

$65,40 \pm 43,78$

*DDE: Maximum permitted $=0,02 \mathrm{mg} / \mathrm{kg}$ 米 $0,56 \pm 0,55$

(According to S.A.G. 1986) (Agricultural and Livestock Service)

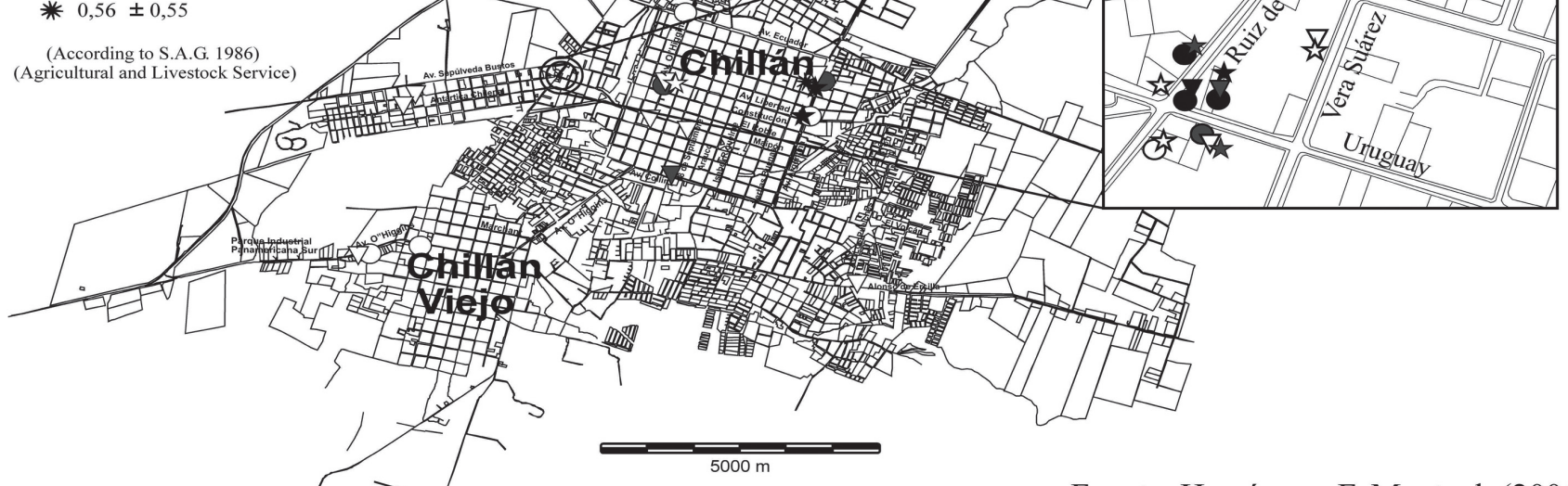

Fuente: Henríquez, F. M. et. al. (2006)

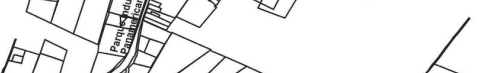

(1/
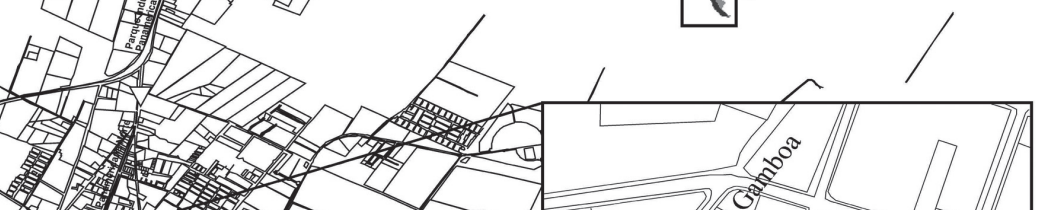

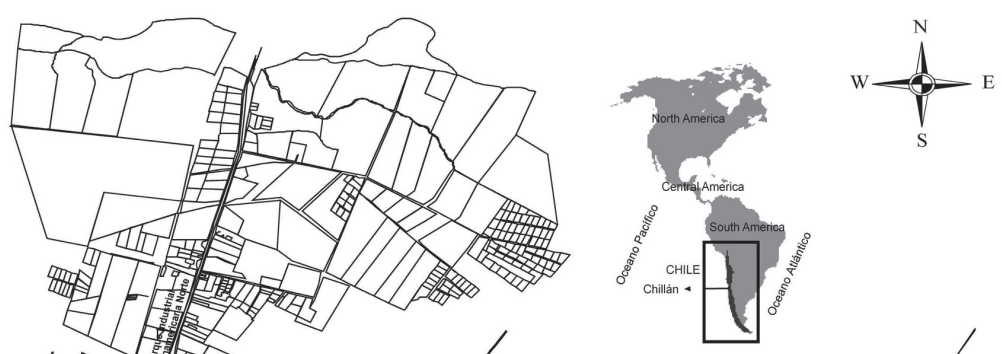
20). The presence of these compounds in urban soil is not regulated in Chile. A comparison of the standards given above for agriculture soils with the soils of Chillán and Chillán Viejo shows that, in both cities, these chemical largely exceed the standards (Tables 1-2, Plan 3) and more critically DDT are higher than the metabolite DDE, which can be interpreted as a recent use of this prohibited pesticide.

Total positive hydrocarbon compounds correlated well with total pesticides and DDT. No correlation was found for total hydrocarbons with Aldrin, and Dieldrin. Total pesticides correlated significantly with DDT and Aldrin. DDT had a high correlation with Aldrin and Aldrin with Dieldrin (Table 3).

Table 3. Pearson correlation coefficients for organochlorine compounds in surface soils from Chillán and Chillán Viejo

$\begin{array}{llll}\text { Total Total Pesticides } & \text { DDT Aldrin }\end{array}$

Total

$\begin{array}{lcccc}\text { Total } & & & & \\ \text { Pesticides } & 0.738 & & & \\ \text { DDT } & 0.980 & 0.996 & & \\ \text { Aldrin } & -0.181 & 0.922 & 0.962 & 0.865 \\ \text { Dieldrin } & -0.156 & 0.505 & 0.260 & 0.865\end{array}$
Viejo

Origin of total hydrocarbons and pesticides in Chillán and Chillán

Total hydrocarbons could reach the soils of both cities via anthropogenic activities like accidental spills and petroleum-derived services supplying transport and vehicular repair. Of the soils found containing total hydrocarbons, $35.3 \%$ were 5 and $10 \mathrm{~m}$ from gas and oil distributors, $23.5 \%$ were at similar distances from tire services, $8.8 \%$ were near mechanical workshops and oil change stations. The lowest percentage of contamination with total hydrocarbons was found near electric workshops and no hydrocarbons were found near turneries, lumber yards, hardware stores, and motor repair shops (Table 4). Other factors also influencing hydrocarbons in urban soils include humid or dry atmospheric depositions from incomplete combustion processes, forest fires, the incineration of agricultural waste in the surrounding rural ecosystem, and urban residential heating emissions (firewood, kerosene, and sawdust) ${ }^{21}$. Such emissions contribute perceptibly to the toxic effects of airborne breathable particles ${ }^{22)}$.

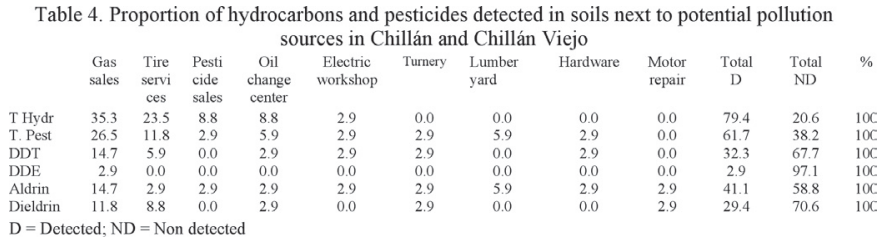

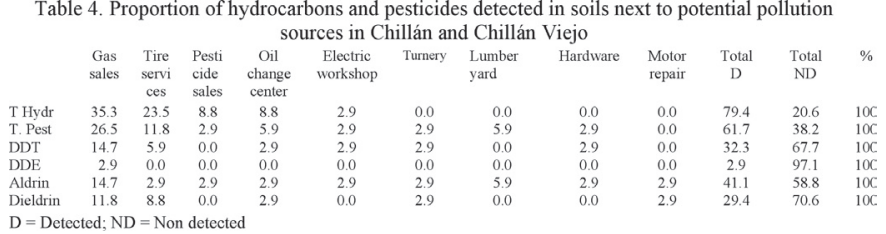

Pesticides in Chillán and Chillán Viejo are due to their residual, persistent properties and their slow dissipation in soil ${ }^{1,23,24)}$ after their use as insecticides for parasite prevention in plants (prior to 1980). DDT was prohibited in $1984{ }^{25}$, Dieldrin in $1987^{26}$, and Aldrin in $1988^{27}$ ). Finally, in 2004, the SAG published an inventory of prohibited pesticides ${ }^{28}$ )

However, the second source of pesticides in urban soil could be the illegal sales and use, although in lesser quantities. For example, $5.9 \%$ of the soils near lumber yards and $2.9 \%$ of those near commercial pesticide and fertilizer offices contain Aldrin. Nonetheless, $2.9 \%$ of the soils near mechanical workshops, oil change centers, electric workshops, turneries, and hardware stores contain DDT and Aldrin. Moreover, the highest percentages of soils with DDT, DDE, Aldrin, and Dieldrin are located near gasoline suppliers and tire services, except for the last, in which Aldrin reached 2.9\% and DDE was not detected (Table 4). The presence of these substances in these locations could be explained by accidental spills during loading and unloading of the compounds; by later 
residual volatilization, in which the compounds are dispersed through the air currents and can adversely affect human health, especially in workers exposed to the compounds for eight or more hours in areas where these chemicals are bought and sold ${ }^{6,29,30,31)}$; and by evaporation ${ }^{6,9)}$; but not by dermal contact with bare contaminated soils ${ }^{6}$, although cancer risks due to exposure to Aldrin and Dieldrin are still under discussion the EPA classifies them as category B2 human carcinogenic agents ${ }^{32)}$.

Relationships of hydrocarbon compounds and pesticides with the physical characteristics of the surface soils.

Some studies suggest that the residual and persistent nature of hydrocarbon and pesticide compounds is due to their adsorption by the organic fraction and humidity in the soil ${ }^{1,9)}$. Analogously, the residual character is established as being due to their adsorption by the clay content in the soil 1,9$)$.

The physical analysis of the soils indicates that $79.6 \%$ of the samples concentrate only $20.3 \pm 10.1 \%$ of the organic matter and the remaining $29.4 \%$ had only $8.8 \pm 1.8 \%$. Furthermore, $61.8 \%$ of the sampled sites had $8.4 \pm 1.9 \%$ of the humidity, $35.3 \%$ had $19.2 \pm 10.2 \%$, and no information regarding humidity was available for the final $3.0 \%$ (Table 1).

The analysis done according to the U.S.D.A. system indicated that most soil textures in the two cities had a high percentage of sand and low percentage of clay (Table 5 ).

Table 5. Soil component proportions for different textures in Chillán and Chillán Viejo

$\begin{array}{lcccr}\begin{array}{l}\text { Surface soil } \\ \text { textures }\end{array} & \text { Samples }(\%) & \text { Sand }(\%) & \text { Mud }(\%) & \text { Clay }(\%) \\ \text { Sandy mud } & 61.8 & 75.2 \pm 52.1 & 44.2 \pm 17.0 & 18.3 \pm 3.7 \\ \text { Muddy sand } & 23.5 & 81.7 \pm 77.0 & 21.6 \pm 13.8 & 6.9 \pm 1.4 \\ \text { Mud } & 8.8 & 51.7 \pm 37.3 & 44.1 \pm 30.0 & 19.4 \pm 16.5 \\ \text { Sand } & 5.9 & 91.6 \pm 87.2 & 12.0 \pm 6.60 & 1.8 \pm 0.8\end{array}$

In these mid-cities, a high correlation was observed only between Dieldrin and total organic matter in the urban soil; such a correlation was not found for any other pesticide or total hydrocarbons. In the latter case, this data coincides with the results obtained by Henríquez et al., in Talcahuano township ${ }^{2,3)}$. All the chemicals analyzed had similarly little significant or negative correlations with clay content and soil humidity (Table 6).

Table 6. Pearson correlation coefficient for soil characteristics and organochlorine compound concentrations in Chillán and Chillán Viejo

$\begin{array}{lccccc} & \begin{array}{c}\text { Total } \\ \text { Hydrocarbons }\end{array} & \begin{array}{c}\text { Total } \\ \text { Pesticides }\end{array} & \text { DDT } & \text { Aldrin } & \text { Dieldrin } \\ \text { Total Organic } & & & & & \\ \text { Matter } & 0.062 & 0.213 & 0.073 & 0.261 & 0.787 \\ \text { Humidity } & -0.178 & 0.148 & 0.238 & -0.124 & 0.323 \\ \text { Sand } & 0.207 & 0.023 & 0.154 & 0.376 & -0.446 \\ \text { Mud } & -0.224 & -0.119 & -0.224 & -0.276 & 0.430 \\ \text { Clay } & -0.110 & 0.144 & -0.044 & -0.338 & 0.344\end{array}$

Maximum total hydrocarbon concentrations were found in sandy soils. The samples from Los Puelches with Alonso de Ercilla (southeast of Chillán) and Vera Suárez 20 (west of Chillán) had total hydrocarbon values of 38.4 and $59.8 \mathrm{mg} / \mathrm{kg}$, indicating demonstrable contamination at these sites. The sample taken at O' Higgins 2879 (southwest of Chillán Viejo) registered $845.5 \mathrm{mg} / \mathrm{kg}$ total hydrocarbons and the samples at Tarapacá 30 and Ruiz de Gamboa (west of Chillán) had 188.4 and $93.7 \mathrm{mg} / \mathrm{kg}$, respectively, indicating the need for soil recovery (Table 1 and Plan 2). In these soils of sandy mud, sand, and muddy sand, leaching is faster and has a greater capacity to stop the pollutants and avoid their movement into underground waters. Low clay contents in bare areas and sparse grasses contribute to this thick texture.

Bare areas and sparse grass coverage present a micro-relief and facilitate periodic flooding from rain and the retention of greater humidity in these soils during autumn-winter. This explains the higher chemical concentrations, considering that the subsoil in most of Chillán and Chillán Viejo includes strata of volcanic flow conglomerates ${ }^{18)}$ with compact clays (thick) that impede drainage to the subsoil. Therefore, studies of deeper samples that could provide relevant historic data would be interesting.

In April 2001, when the sampling was done, the cities had $61.0 \mathrm{~mm}$ of precipitation, with a maximum of $33.2 \mathrm{~mm}$ in $24 \mathrm{~h}$ and total accumulated rain for the month of $133.0 \mathrm{~mm}^{33)}$. The average maximum temperature in April 2001 was $19.6^{\circ} \mathrm{C}$, the average minimum was $6.4^{\circ} \mathrm{C}$, and the average for the month was $12.4^{\circ} \mathrm{C}$. Maximum evaporation in $24 \mathrm{~h}$ reached $5.7 \mathrm{~mm}$ whereas total evaporation for the month was $84.7 \mathrm{~mm}^{33)}$.

Surface humidity in urban soils was associated with urban expansion onto inadequate lands of fluvial origins, variable textures, and heterogeneous mixtures of clay, mud, sand, and scant gravel. These lands are generally saturated at shallow depths, causing the surface soil to remain humid. Since Aldrin and Dieldrin rarely leach in water, Dieldrin persisted in the soil for five years at these latitudes ${ }^{34)}$, unlike tropical regions where it disappears in one month due to higher temperatures and evaporation ${ }^{35}$.

\section{Hydrocarbon and pesticide distribution by soil use.}

The greatest proportions of total hydrocarbons and pesticides in both cities were distributed in bare surface soils. Likewise, this type of ground cover was the only one in which the metabolite DDE was found. This can be explained by some chemical or biological process occurring in the presence of compact, humid soil. The scarcity of organic matter, clay, and some undetermined process could impede the breakdown of DDT into DDE. When bare, the soil freely adsorbs chemical elements without the obstacle granted by natural coverage with grasses, lawns, or scarce grass and the compactness of the soil (Table 7).

\begin{tabular}{|c|c|c|c|c|c|c|}
\hline & $\begin{array}{c}\text { Total } \\
\text { Hydrocarbons }\end{array}$ & $\begin{array}{c}\text { Total } \\
\text { pesticides }\end{array}$ & DDT & DDE & Aldrin & Dieldrin \\
\hline Sparse Grass & 18.0 & 12.0 & 6.0 & 0.0 & 12.0 & 3.0 \\
\hline Bare & 49.0 & 43.0 & 21.0 & 2.9 & 26.0 & 24.0 \\
\hline Lawn & 9.0 & 6.0 & 6.0 & 0.0 & 0.0 & 6.0 \\
\hline Grass & 3.0 & 3.0 & 3.0 & 0.0 & 3.0 & 0.0 \\
\hline Non detected & 21.0 & 36.0 & 64.0 & 97.1 & 59.0 & 67.0 \\
\hline Total (\%) & 100 & 100 & 100 & 100 & 100 & 100 \\
\hline
\end{tabular}

In conclusion, the results indicate that the residual and persistent nature of pesticides, total hydrocarbons, and their adsorption onto organic molecules, clay content, and soil humidity, is a complex process established by the balance between adsorption in soil colloids, transformation or degradation, loss in gas or liquid form and, at the same time, by the type of clay and soil $\mathrm{pH}$, which are determinant in the availability of xenobiotics. A partial correlation exists between pesticide concentration and hydrocarbons with soil texture and organic matter ${ }^{36)}$. Urban expansion and increased economic activities derived from different needs are, without a doubt, having a negative impact on the soil, due essentially to commerce and the use of petroleum derivatives to satisfy agricultural and vehicular needs. The impact of pesticides is related with phytosanitary use and commerce. The presence of pesticide substances could also originate in fill dirt coming from river shorelines that receive diffuse contamination and agricultural and urban soils and stubble prior to urbanization, caused by the high water table in this flat, slightly hilly area.

\section{ACKNOWLEDGEMENTS}

This research is part of the first author's doctoral thesis in the Programa de Ciencias Ambientales, Centro EULA-Chile, Universidad de Concepción. FONDECYT Project No. 1000828 is acknowledged for funding and the Universidad del Bío-Bio for its support.

\section{REFERENCES}

1. S. González M. Estado de la contaminación de los suelos en Chile. Estación Experimental La Platina. Instituto de Investigaciones Agropecuarias. In: Environment and Sustainability, Chile USACH. http://lauca.usach.cl/ima cap11.htm\#inicio. (2003)

2. M.HenríquezF., J. Becerra, R. Barra. Distribución espacial de hidrocarburos aromáticos en suelos superficiales de la Comuna de Talcahuano. VIII Región, Chile. Anales de la Sociedad Chilena de Ciencias Geográficas 50 - 62. Santiago, Chile. (1999)

3. M. Henríquez F. Factores que inciden en la deposición de hidrocarburos aromáticos en suelos de Talcahuano, VIII Región. Chile. Revista Geográfica de Valparaíso, Vol. 32-33: 163-181. Valparaíso, Chile. (2001-2002)

4. R. Barra, P. Popp, R. Quiroz, C. Bauer, H. Cid and W von Tumpling. Persistent toxic substances in soils and waters along an altitudinal gradient in the Laja River basin South Central Chile. Chemosphere 58,905-915. (2005). 
5. Z. Wang, D.M. Friedrich, M.R. Beversluis, A.G. Joly, M.H. Huesemann, M.J. Truex, R.G. Riley, C.J. Thompson, B.M. Peyton. A spectrocopic study of phenanthrene adsortiption on porous silica. Environ. Mol. Sci. Lab. (1999)

6. M. Deogracias, L. Yánez, F. Díaz-Barriga. Comportamiento ambiental del DDT y de la deltametrina. Laboratorio de toxicología ambiental, Facultad de Medicina, Universidad Autónoma de San Luis de Potosí, México. pp. 1-39. (2003)

7. PAN Pesticides Database. Physical characteristics of the pesticides Pesticide Action Network North America. California, USA. April 8, (2005).

8. A. Baert. Comentarios ó respeito dos riscos ligados á recollida do fuel pesado do Prestige no caso de que acade a costa francesa, e á limpeza das aves afectadas, en funcion dos datos disponibles a 29 de novembro do 2002. Translated into Spanish by María de la Fuente Noriega. Universidad Alfonso X el Sabio, Madrid, España. (2002)

9. E. Galán, J.L. Gómez, J. Aguilar. Contaminación de suelos por compuestos orgánicos. Consejería de Medio Ambiente de la Junta de Andalucía. Universidades de Sevilla y Huelva, España, pp. 6-85. (2003)

10. A. Gaynor. Contaminación del suelo con pesticidas, estudio de caso de Perth, Australia Occidental. The University of Western Auatralia, Perth. (2001)

11. R. Barra, K. Pozo, R. Urrutia et al. Plaguicidas organoclorados persistentes en sedimentos de tres lagos costeros y un lago andino de Chile central. Bol. Soc. Chil. Quím. [online]. jun. 2001, vol.46, no.2 [cited 04 September 2004], p.149-159. Available on the World Wide Web: <http://www.scielo. cl/scielo.php?script=sci_arttext\&pid=S0366-16442001000200008\&lng=e s\&nrm=iso $>$. ISSN 036б-1644.

12. Science Subgroup. South Florida ecosystem restoration: Scientific information neeeds. Report to the Working Group of the South Florida EcosystemRestoration Task Force. (1996) http://everglades.fiu.edu/ taskforce/scineeds/contam.pdf

13. Danish EPA. Presentation of Danish policies and activities in the field of chemicals and pesticides. Printed version of this publication is available from Frontlinien - Information and Books, e- mail: frontlinien@frontlinien. dk. (2000)

14. Fundación Mapfre. Manual de Contaminación Ambiental. Editorial Mapfre, S.A. Barcelona, España. (1994)

15. M. Henríquez F. Uso urbano y diferenciación socio espacial de Chillán. Anales de la Sociedad Chilena de Ciencias Geográficas: 167-181. Santiago, Chile. (2001)

16. Pastor, A., Vásquez E., Ciscar R., De la Guardia M., "Efficiency of the microwave-assisted extraction of hydrocarbons and pesticides from sediments"; Analytica Chimica Acta, 344 (241-249), (1997).

17. SAG Servicio Agrícola y Ganadero. Fija nivel máximo de residuos de plaguicidas clorados en empastadas para efectos sancionatorios. Decreto No. 1437. Ministerio de Agricultura. Santiago, República de Chile. (1986)

18. M. Mardones F. Los riesgos naturales en el sitio de la ciudad de Chillán: riesgo sísmico, de inundación y de anegamiento. En: Serie de ciudades intermedias, Geoespacios-4. (1990)

19. Quince Claude, Ayres. La erosión del suelo y su control. Ediciones Omega S.A Barcelona, España. (1960)
20. Ministerio de Salud. Aprueba reglamento sanitario sobre manejo de residuos peligrosos. No. 148. Santiago, República de Chile. (2003)

21. M. Henríquez F. Evaluación de la sustentabilidad de Chillán según percepción ciudadana.

22. M. Adonis, V. Martínez, R. Riquelme, P. Ancic, G. González, R. Tapia, M. Castro, D. Lucas, F. Berthou, L. Gil. Susceptibility and exposure biomarkers in people exposed to PAHs from diesel exhaust. Toxicol Lett 144, 1: 3-15. (2003)

23. ATSDR. Aldrin and Dieldrin. An ATSDR Factsheet. Enviro Tools: 1-5. Michigan State University- National Institute of Environmental Health Sciences. (2002)

24. P. Orris, L. Kaatz Chary, K. Perry, J. Asbury. Persistent organic pollutants (POPs) and human health. WFPHA: 3-45, Washington, DC. (2000)

25. SAG Servicio Agrícola y Ganadero. Resolución No. 639 del 07/05/84. Prohíbe la importación, fabricación, venta, distribución y uso del plaguicida DDT. Ministerio de Agricultura. Santiago, República de Chile (1984)

26. SAG Servicio Agrícola y Ganadero. Prohíbe la importación, fabricación, venta, distribución y uso de los plaguicidas Dieldrin, Endrin, Heptacloro y Clordan. Decreto No. 2142. Santiago, República de Chile (1987)

27. SAG Servicio Agrícola y Ganadero. Resolución No 2.003 del 22/11/88. Prohíbe la importación, fabricación, venta, distribución y uso del plaguicida Aldrin. Ministerio de Agricultura. Santiago, República de Chile (1988)

28. A. Correa. Inventario Nacional de Plaguicidas Caducados COPs. Publicación de la Asociación Chilena de Control de Plagas A.G. Santiago Chile, pp. 121-127 (2004).

29. R. Stiller-Winkler, W. Hadnagy, G. Leng, E. Straube, H. Idel. Immunological parameters in humans exposed to pesticides in the agricultural environment. Toxicol Lett Vol. 107, 1-3: 219-224. (1999)

30. C.-H. Li, C.-C. Lee, Y.W. Cheng, H.-A. Juang, J.-J. Kang. Activation and up-regulation of nitric oxide synthase in human umbilical vein endotelial cells by polycyclic aromatic hydrocarbons. Toxicol Lett Vol. 151, 2: 367374. (2004)

31. M.M. Amr. Pesticide monitoring and its health problems in Egypt a Third World country. Toxicol Lett Vol. 107, 1-3: 1-13. (1999)

32. D.E. Stevenson, E.F. Walborg Jr, D. Warner North, R.L. Sielken Jr., C.E. Ross, A.S. Wright, Y. Xu, L.M. Kamendulis, J.E. Klaunig. Monograph: Reassessment of human cancer risk of aldrin/dieldrin. Toxicol Lett Vol. 109, 3: 123-186. (1999)

33. Universidad de Concepción. Boletín Agrometeorológico. April 2001, No. 4. Facultad de Ingeniería Agrícola. Departamento de Riego y Drenaje. Chillán, Chile. (2001)

34. WFPHA (World Federation of Public Health Associations) Persistent Organic Pollutants and the Human Health. Chicago, USA. May, (2000)

35. GPA (Global Programme of Action for the Protection of the Marine Environment from Land-based Activities). Aldrin and Dieldrin. USA. (2001).

36. R. Jiménez B. Comportamiento del suelo ante procesos de contaminación. Terceras Jornadas sobre Suelos Contaminados. Serie Monografías. Ministerio de Medio Ambiente. Dirección General de Calidad y Evaluación Ambiental: 41-56 ISBN 84-8320-065-1. Madrid, España. (1998). 